\title{
STUDI KORELASI DISIPLIN BELAJAR DENGAN PRESTASI BELAJAR PENDIDIKAN AGAMA HINDU DAN BUDI PEKERTI SISWA KELAS V SD SARASWATI 5 DENPASAR
}

\author{
Oleh: \\ Ni Putu Sinta \\ putusinta96@gmail.com \\ I Ketut Sukrawa \\ iketutsukrawa@unhi.ac.id \\ W.A.Sindhu Gitananda \\ sindhugitananda@gmail.com \\ Universitas Hindu Indonesia Denpasar
}

\begin{abstract}
ABSTRAK
Keberhasilan belajar pada mata pelajaran Agama Hindu dan Budi Pekerti, dapat dilihat dari hasil belajar kognitif berupa prestasi belajar dan hasil afektif berupa budi pekerti. Penelitian ini bertujuan untuk menguji hipotesis bahwa Disiplin Belajar $\left(\mathrm{X}_{1}\right)$ berkorelasi positif yang signifikan dengan prestasi belajar pendidikan agama Hindu dan Budi Pekerti siswa kelas V SD 5 Saraswati Denpasar $\left(\mathrm{Y}_{1}\right)$ dan (Y2). Penelitian ini dilaksanakan sesuai rancangan ex-post facto; variabelnya tidak bisa dimanipulasi dan sifatnya sudah terjadi. Hasil penelitian memperlihatkan terdapat korelasi yang positif signifikan antara disiplin belajar dengan prestasi belajar, dengan koefisien korelasi hitung sebesar 0,512 > r tabel 0,197 dan sebesar 0,151 masing-masing pada taraf 1\% dan 5\%, dengan jumlah subyek 169. Di samping itu juga terdapat korelasi yang positif signifikan antara disiplin belajar dengan budi pekerti siswa, dibuktikan dengan koefisien korelasi hitung sebesar 0,746 > r tabel 0,197 dan sebesar 0,151 masing-masing pada taraf $1 \%$ dan 5\%, dengan jumlah subyek 169 . Temuan ini dapat dijadikan dasar untuk menerima $\mathrm{h}\left(\mathrm{Ha}_{2}\right)$ disiplin belajar $\left(\mathrm{X}_{1}\right)$ berkorelasi positif yang signifikan dengan budi pekerti siswa kelas V SD Saraswati 5 Denpasar $\left(\mathrm{Y}_{2}\right)$.
\end{abstract}

Kata kunci: Studi Korelasi, Disiplin Belajar, Prestasi Belajar, Budi

\begin{abstract}
To succeed in learning the subject of Hindu Religion and Character can be assessed from the cognitive learning outcomes in the form of learning achievement and affective outcomes in the form of character. This study aims at testing the hypothesis that Learning Discipline (X1) has a significant positive correlation with the learning achievement of the Hindu Religion and the
\end{abstract}


Character of the fifth grade students of SD 5 Saraswati Denpasar (Y1) and (Y2). This research was conducted according to an ex-post facto design; the variable cannot be manipulated and its nature already occurred. The results shows that there was a significant positive correlation between learning discipline and learning achievement, with a correlation coefficient of 0.512> r table 0.197 and 0.151 respectively at the level of $1 \%$ and $5 \%$, with the number of subjects 169 . In addition, there was also a correlation which was significant and positive between the learning discipline and student character, evidenced by the arithmetic correlation coefficient of $0.746>r$ table 0.197 and 0.151 respectively at the level of $1 \%$ and 5\%, with the number of subjects 169. These findings can be used as a basis for accepting $h$ ( Ha2) learning discipline (X1) has a significant positive correlation with the character of the fifth grade students of SD Saraswati 5 Denpasar (Y2).

Keywords: Correlation Study, Learning Discipline, Learning Achievement, Character

\section{PENDAHULUAN}

Pada hakekatnya Pendidikan Agama Hindu dan Budi Pekerti adalah pembentuk moral bangsa yang bersumber dari Kitab Suci Veda, yang selalu mengarah pada konsep Tri Kaya Parisudha (berpikir yang baik, berkata yang baik, dan berbuat yang baik) demi terwujudnya manusia yang berbudi pekerti luhur. Tujuannya antara lain menumbuhkembangkan dan meningkatkan kualitas Sradha dan Bhakti kepercayaan dan penghormatan melalui pemberian motivasi serta pengamalan ajaran agama Hindu. Kemudian menumbuhkan insan Hindu yang dapat mewujudkan nilai-nilai Mokshartham Jagadhita ya ca ithi dharma dalam kehidupannya ( Duwijo dan Darta, 2014:4). Mohamad Nuh, Menteri Pendidikan dan Kebudayaan dalam Duwijo dan Darta (2014) menyatakan bahwa pengetahuan agama yang dipelajari para peserta didik menjadi sumber nilai dan penggerak perilaku mereka. Sekadar contoh, di antara nilai budi pekerti dalam agama Hindu dikenal dengan Tri Marga (bhakti kepada Tuhan, orang tua, dan guru; karma, bekerja sebaik-baiknya untuk dipersembahkan kepada orang lain dan Tuhan; Jnana, menuntut ilmu sebanyak-banyaknya untuk bekal hidup dan penuntun hidup), dan Tri Warga (dharma, berbuat berdasarkan atas kebenaran; artha, memenuhi harta benda kebutuhan hidup berdasarkan kebenaran, dan kama, memenuhi keinginan sesuai dengan norma-norma yang berlaku). Dalam pembentukan budi pekerti, proses pembelajarannya mesti mengantar mereka dari pengetahuan tentang kebaikan, lalu menimbulkan komitmen terhadap kebaikan, dan akhirnya benar-benar melakukan kebaikan.

Kemudian, untuk mengetahui kemampuan peserta didik dalam pembelajaran Agama Hindu dan Budi Pekerti, dapat ditunjukkan dengan hasil belajar yang diperolehnya. Menurut Sudjana 
(2013:3), hasil belajar siswa adalah hasil perubahan tingkah laku yang mencakup bidang kognitif, afektif dan psikomotor. Jadi hasil belajar agama Hindu dan Budi Pekerti adalah hasil belajar yang ditunjukkan dari hasil daripada aspek pengetahuan (prestasi belajar),sikap (budi pekerti),dan ketrampilan. Namun faktanya, penilaian kemampuan siswa hanya menekankan pada aspek kognitif yakni prestasi belajar. Cenderung mengabaikan aspek afektif (sikap dan perilaku) dan psikomotor. Padahal, pembentukan Budi Pekerti menjadi salah satu output dari pembelajaran Agama seperti yang disampaikan Mohamad Nuh di atas.

Fenomena degradasi moral anak-anak dan remaja baik di lingkungan sekolah, rumah, dan masyarakat menjadi salah satu tantangan bagi pendidik Agama Hindu dan Budi Pekerti. Seperti yang dikemukakan Bagong Suyanto, Guru Besar FISIP Universitas Airlangga pada kolom republika.co.id, salah satu faktor penyebab kasus remaja yang melakukan kekerasan pada gurunya di SMA Negeri 1 Sampang pada bulan Februari 2018, dikarenakan arah perkembangan iklim pembelajaran yang belakangan ini cenderung makin kompetitif, dan kurang membuka kesadaran siswa tentang arti penting solidaritas, dan toleransi. Pendidikan karakter dan pelajaran tentang budi pekerti, tidak dikembangkan dengan serius. Seorang siswa seharusnya menaati tata tertib belajar di kelas, namun yang terjadi, siswa yang bersangkutan menganiaya gurunnya. Maka dari itu, siswa patut melatih disiplin dalam belajar Agama dan
Budi Pekerti untuk menggapai hasil belajar baik itu ranah kognitif, afektif, dan psikomotor. Ketika siswa menerapkan disiplin dalam belajar , maka ia akan memiliki kesadaran untuk menjalankan kewajibannya meraih prestasi belajar dan budi pekerti.

SD Saraswati 5 Denpasar merupakan salah satu sekolah swasta di Denpasar, yang mengajak siswanya untuk memiliki kesadaran disiplin diri sejak dini. Aturan belajar dan sanksi tegas yang diberlakukan menjadi salah satu bagian pembiasaan daripada sikap disiplin belajar. Salah satunya, ditunjukkan dengan penggunaan buku penghubung yang intensif sebagai buku pemantau, catatan harian atau jadwal belajar sebagai bukti telah melaksanakan kewajibannya di rumah dan di sekolah. Kepala Sekolah dan Guru berharap dengan dilaksanakannya disiplin belajar, maka siswa dapat meraih keberhasilan belajar termasuk pada pembelajaran Agama Hindu dan Budi Pekerti. Dilihat dari implementasi disiplin belajar dalam proses pembelajaran Agama Hindu dan Budi Pekerti di kelas, ada beberapa siswa yang telah melaksanakan disiplin belajar dalam pembelajaran Agama Hindu dan Budi Pekerti, adapula yang masih terkena hukuman karena tidak menyelesaikan pekerjaan rumah yang diberikan oleh guru, tidak memperhatikan guru pada proses pembelajaran, dan tindakan tidak disiplin lainnya.Padahal disiplin belajar selain sebagai pendukung keberhasilan belajar pada ranah pengetahuan, juga mengantarkan seseorang pada sikap dan perilaku 
merupakan penelitian tentang variabel yang kejadiannya sudah terjadi sebelum penelitian dilaksanakan. Subyek penelitian berjumlah 169 orang yang merupakan siswa siswi kelas V SD Saraswati 5 Denpasar. Instrument yang dipergunakan berupa kuesioner tertutup. Menurut Sumarni (2012:149), kuesioner tertutup berisi pernyataan -pernyataan yang disertai sejumlah alternatif jawaban yang disediakan. Skala yang digunakan adalah skala Likert, (1) Selalu; (2) Sering; (3) Kadang-kadang; (4) Hampir Tidak Pernah; (5) Tidak pernah. Pernyatan positif berturutturut diberikan skor 5,4,3,2,1 dan pernyataan negative berturut-turut diberikan skor 1,2,3,4,5.

Kuesioner dalam penelitian ini terdiri dari kuesioner disiplin belajar dan budi pekerti. Disiplin belajar dijabarkan kedalam 5 indikator yaitu (1) Taat, Tertib, Teratur, Aktif, Rajin, Responsive mengikuti proses pelajaran Agama Hindu dan Budi Pekerti di kelas; (2) Teratur menunjukkan sikap yang berdasarkan ajaran Agama Hindu dan Budi Pekerti di sekolah; (3) Rajin dan Teratur belajar Agama Hindu dan Budi Pekerti di rumah; (4) Teratur menunjukkan sikap yang berdasarkan pada ajaran Agama Hindu dan Budi Pekerti di rumah; (5) Teratur menunjukkan sikap yang berdasarkan ajaran Agama Hindu dan Budi Pekerti di masyarakat. Selanjutnya, variabel budi pekerti dijabarkan menjadi 4 indikator yaitu (1) menunjukkan sikap dan perbuatan sehari-hari yang merupakan pengejewantahan ajaran ahimsa; (2) Menunjukkan sikap dan perbuatan sehari-hari yang merupakan pengejewantahan ajaran satya; (3) Menunjukkan sikap dan perbuatan sehari-hari yang merupakan pengejewantahan ajaran bhakti terhadap Catur Guru; (4) Menunjukkan sikap dan perbuatan menjaga kelestarian tempat suci.

\begin{tabular}{llr}
\multicolumn{2}{c}{ Pengujian } & validitas \\
instrument penelitian & berupa \\
kuesioner disiplin belajar & dan budi \\
pekerti & dilaksanakan di & SD
\end{tabular} Dwijendra Denpasar. Uji validitas dilaksanakan, sebelum peneliti melakukan penelitian di SD Saraswati 5 Denpasar. Peneliti mengambil 30 siswa di kelas V SD Dwijendra Denpasar sebagai subjek penelitian pada uji validitas instrument. Pengukuran validitas kuesioner dalam penelitian ini menggunakan rumus kolerasi product moment sebagai berikut.

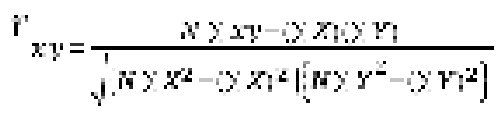

(Arikunto, 2014:87)

\section{Keterangan :}

$\mathrm{r}_{\mathrm{xy}}=$ koefisien korelasi

$\sum X \quad$ jumlah skor butir

$\sum \mathrm{Y}=$ jumlah skor total

$\mathrm{N} \quad=$ jumlah responden

Kriteria yang akan digunakan dalam uji validitas pada kuesioner adalah dengan membandingkan $\mathrm{r}_{\mathrm{xy}}$ dengan $r$ tabel pada taraf signifikasi 5\% ketentuan yang digunakan yakni jika $r_{x y}$ dikatakan valid apabila $r_{x y}>$ $\mathrm{r}_{\text {tabel. }}$. Berdasarkan rumus korelasi product moment, dan dikonsultasikan pada $\mathrm{r}$ tabel, Dari 52 pernyataan kuesioner disiplin belajar, maka terdapat 50 pernyataan yang valid. Item soal tersebut valid dikarenakan nilai $r_{x y}>r_{\text {tabel }}$. Adapun 2 pernyataan 
yang tidak valid dikarenakan nilai $r_{x y}<r_{\text {tabel }}$. Selanjutnya 2 pernyataan yang tidak valid tersebut, tidak dipergunakan oleh peneliti untuk memperoleh data.Selanjutnya, dari 48 pernyataan kuesioner Budi Pekerti yang dipergunakan, 40 pernyataan yang valid. Adapun 8 pernyataan yang tidak valid dikarenakan nilai $r_{x y}<r_{\text {tabel }}$. Kemudian 8 pernyataan yang tidak valid tersebut, tidak dipergunakan oleh peneliti untuk memperoleh data.

Pengujian instrument pada tahap selanjutnya adalah pengujian reliablitas instrument. Suatu instrument pengukuran dikatakan reliabel jika pengukurannya konsisten, cermat dan akurat. Untuk menentukan koefisien reliabilitas digunakan rumus koefisien alpha cronbach karena instrument penelitian berupa pernyataan, maka rumus yang dapat digunakan yakni:

$$
r_{11}=\left(\frac{n}{(n-1)}\right)\left(1-\frac{\sum \sigma_{i}^{2}}{\sigma_{!}^{2}}\right)
$$

(Arikunto, 2014:122)

Keterangan :

$\mathrm{r}_{11}=$ reliabilitas yang

dicari atau koefisien realibilitas

$\sum \sigma_{i}^{2}=$ jumlah varians skor tiap-tiap butir

$\sigma_{\mathrm{t}}^{2}=$ varians total

$\mathrm{n}=$ jumlah butir

kuesioner yang akan diuji

reliabilitasnya

Untuk menentukan kriteria realibilitas yang telah didapat dari rumus alapa croanbrach, maka peneliti dapat mengkonsultasikannya pada tabel 3.3.6 Kategori Koefisien Korelasi berikut ini:
Kategori Koefisien Reliabilitas

\begin{tabular}{|c|c|}
\hline $\begin{array}{c}\text { Koefisien } \\
\text { Korelasi }\end{array}$ & $\begin{array}{c}\text { Kriteria } \\
\text { Reliabilitas }\end{array}$ \\
\hline $0.80-1,00$ & Sangat Tinggi \\
\hline $0,60-0,80$ & Tinggi \\
\hline $0,40-0,60$ & Sedang \\
\hline $0,20-0,40$ & Rendah \\
\hline Sumber : Guilford dalam
\end{tabular}

(Nasrul Setiawan:2012)

Berdasarkan hasil analisis dengan menggunakan rumus alpha cronbach tersebut, maka diperoleh koefisien reliabilitas kuesioner disiplin belajar sebesar 0,955, yang memiliki kriteria realibilitas sangat tinggi dan dianggap reliabel untuk mencari data yang dipergunakan untuk menganalisis data. Selanjutnya, koefisien realibilitas kuesioner budi pekerti diperoleh 0,963 , yang memiliki kriteria realibilitas sangat tinggi, dan dianggap reliable untuk menganalisis data. Pengumpulan data prestasi belajar siswa diperoleh dengan mencatat dokumen dari nilai rapor siswa siswi yang beragama Hindu kelas V semester ganjil tahun ajaran 2017/2018.

Teknik analisis data yang dipergunakan adalah korelasi product moment, menggunakan spss 20 for windows, untuk menganalisis korelasi disiplin belajar dengan prestasi belajar; serta disiplin belajar dengan budi pekerti, dapat dilihat pada rumus berikut ini:
1) Korelasi Disiplin Belajar terhadap Prestasi Belajar Siswa

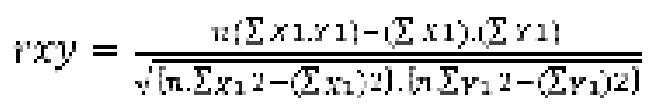


2) Korelasi Disiplin Belajar dengan Budi Pekerti Siswa

Sumber: Sudijono, (2012:206)

Keterangan :

$\mathrm{r}_{\mathrm{xy}} \quad:$ koefisien korelasi

$\mathrm{n} \quad$ : jumlah subyek

$\sum \mathrm{X}_{1} \quad:$ jumlah seluruh skor

disiplin belajar

$\sum \mathrm{Y}_{1} \quad$ : jumlah seluruh skor prestasi belajar

$\Sigma Y_{2} \quad:$ jumlah seluruh skor budi pekerti siswa

$\sum \mathrm{X}_{1}{ }^{2} \quad$ : jumlah kuadrat disiplin belajar

$\sum \mathrm{Y}_{1}{ }^{2} \quad$ : jumlah kuadrat prestasi belajar

$\Sigma \mathrm{Y}_{2}{ }^{2} \quad$ : jumlah kuadrat budi pekerti

\section{PEMBAHASAN}

\section{a. Korelasi Disiplin Belajar dengan Prestasi Belajar}

Berikut adalah hasil korelasi disiplin belajar dengan prestasi belajar siswa kelas V SD Saraswati 5 Denpasar, dengan mempergunakan korelasi product moment pada spss 
Pendidikan Agama Hindu dan Budi Pekerti siswa kelas V SD Saraswati 5 Denpasar $\left(\mathrm{Y}_{1}\right)$.

Menurut Tulus (2004: 15), seorang siswa yang berusaha menata dirinya terbiasa dengan hidup tertib, teratur, menaati peraturan, dan norma yang berlaku di sekolah, ia akan menggapai keberhasilan dan turut andil dalam prestasi belajarnya. Menurut Darmadi (2017:328), disiplin siswa dalam belajar atau disiplin belajar merupakan hal yang sangat penting karena jika kedisiplinan tersebut telah tertanam dalam diri anak, maka ia berusaha untuk belajar secara teratur, continue, dan ajeg sesuai dengan peraturanperaturan yang ada, sehingga akan tercapai sebuah prestasi dalam belajar. Dalam kitab Atharva Veda (XI.5.17) juga disebutkan pentingnya disiplin pada masa brahmacari dan manfaatnya sebagai berikut:

Brahmacaryena tapasa raja rastram vi raksati,

Acaryo brahmacayerna

brahmacarinam icchate

Brahmacayerna kanya

yuvanam vindate patim

Brahmacayerna tapasa deva mrtyum apaghnata

Indro ha brahmacayerna devebhyah svar abharat

Artinya:

dengan disiplin atau tapas brahmacarya, raja melindungi kerajaannya. Dengan disiplin brahmacarya guru mengharap keberhasilan siswanya, Dengan disiplin brahmcarya seorang gadis mendapat suami yang tampan, dan Indra dengan

\author{
brahmacarya memberikan \\ kecemerlangan surgawi \\ kepada yang bersina. \\ (Sandika, 2014: 52)
}

Berdasarkan sloka Atharwa Weda tersebut, maka ditegaskan bahwasanya seorang sisya atau brahmacarya yang disiplin akan memberikan manfaat salah satunya adalah guru mengharap keberhasilan daripada sisya. Jika dikaitkan dalam pembelajaran Agama Hindu dewasa ini, seorang sisya yang menerapkan kedisiplinan dalam masa brahmacari atau masa menutut ilmu, maka guru akan mengharapkan keberhasilan siswanya dalam belajar, yang ditunjukkan dengan prestasi belajarnya. Pernyataan dan sloka di atas, memperkuat hasil penelitian ini yaitu disiplin belajar berkorelasi positif yang signifikan dengan prestasi belajar. Kenaikan skor disiplin belajar diikuti kenaikan skor prestasi belajar, sebaliknya penurunan skor disiplin belajar diikuti penurunan skor prestasi belajar.

Hasil penelitian ini memiliki validitas dan reliabilitas yang terbatas, karena dalam penelitian ini ada sejumlah variabel lain yang tentunya memiliki korelasi dengan prestasi belajar siswa dalam mata pelajaran pendidikan Agama Hindu tetapi tidak di perhitungkan. Hal ini tentu karena peneliti tidak meneliti variabel-variabel lainnya yang ikut berkorelasi prestasi belajar. Hasil penelitian ini haruslah dipergunakan secara hati-hati dan seksama sebagai dasar dalam membuat keputusan yang menyangkut pendidikan agama Hindu dan Budi Pekerti khususnya. 


\section{b. Korelasi Disiplin Belajar dengan Budi Pekerti}

Berikut adalah hasil korelasi disiplin belajar dengan budi pekerti siswa kelas V SD Saraswati 5 Denpasar, dengan mempergunakan korelasi product moment pada spss 20 for Windows :

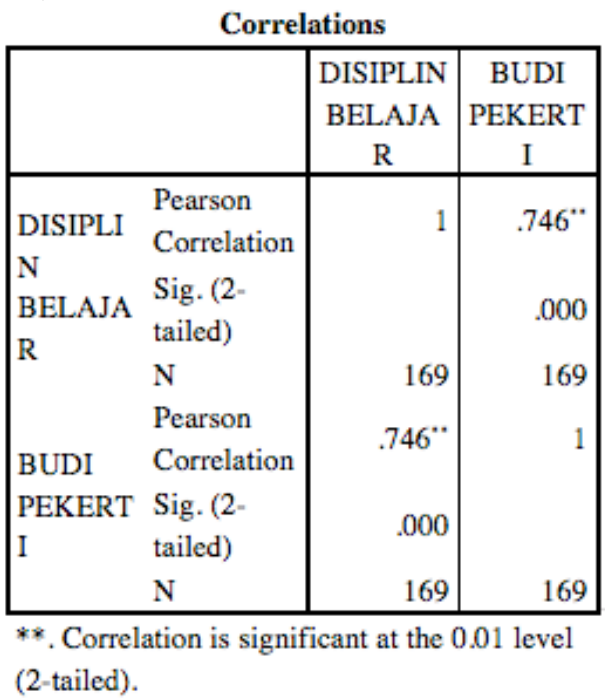

Hasil tersebut dapat dijabarkan sebagai berikut: pertama, terdapat korelasi positif dan signifikan antara disiplin belajar dengan budi pekerti dibuktikan dengan koefisien korelasi hitung sebesar 0,746 yang lebih besar dari nilai $r$ tabel sebesar 0,197 dan sebesar 0,151 masing-masing pada taraf signifikan $1 \%$ dan taraf signifikan 5\%, dengan $\mathrm{n}=169$. Kedua, korelasi antara disiplin belajar dengan budi pekerti siswa merupakan korelasi sejajar searah, yang artinya kenaikan skor disiplin belajar diikuti kenaikan skor budi pekerti, sebaliknya penurunan skor disiplin belajar diikuti penurunan skor budi pekerti. Temuan ini dapat dijadikan dasar untuk menerima hipotesis alternatif yang kedua yang dikemukakan dalam penelitian ini yaitu; $\left(\mathrm{Ha}_{2}\right)$ disiplin belajar $\left(\mathrm{X}_{1}\right)$ berkorelasi positif yang signifikan dengan Budi Pekerti siswa kelas V SD Saraswati 5 Denpasar $\left(\mathrm{Y}_{2}\right)$.

Menurut Sofiyati (2012: 20) disiplin apabila dikembangkan dan diterapkan dengan baik, konsisten dan konsekuen akan berdampak postif pada kehidupan dan perilaku siswa. Disiplin dapat mendorong mereka belajar secara konkret dalam praktek hidup di sekolah dengan halhal positif, yaitu melakukan hal-hal yang lurus dan benar serta menjauhi hal-hal negatif. Ini menunjukkan ketika siswa melaksanakan disiplin belajar dalam mata pelajaran Agama Hindu dan Budi Pekerti maka ia akan menunjukkan daripada sikap dan perilaku yang mencerminkan budi pekerti luhur. Menurut Tulus (2004:89) juga menyatakan pelaksanaan peraturan sekolah yang ketat dan konsisten telah memberi pengaruh positif bagi terbentuknya perilaku yang baik bagi siswa. Kesadaran diri untuk melakukan perilaku yang lebih baik dari sebelumnya, merupakan salah satu keberhasilan penerapan disiplin dalam belajar. Siswa juga akan mampu membedakan mana perbuatan yang baik dan buruk, yang tentunya searah dengan normanorma yang berlaku di lingkungan sekolah, keluarga, dan masyarakat. Pernyataan di atas, memperkuat hasil penelitian ini, bahwasanya disiplin belajar berkorelasi positif yang signifikan dengan budi pekerti. Kenaikan skor disiplin belajar diikuti kenaikan skor budi pekerti, sebaliknya penurunan skor disiplin belajar diikuti penurunan skor budi pekerti. 
Menurut kemendikbud dalam Dwija dan Darta (2014) tujuan pendidikan Agama Hindu dan Budi Pekerti yang berlandaskan Kitab Suci Veda antara lain membentuk peserta didik memiliki sraddha dan bhakti, berakhlak mulia, berbudi pekerti luhur yang tercermin dalam perilaku sehari-hari, menjalin hubungan yang selaras, serasi dan seimbang antara manusia dengan Sang Hyang Widhi, manusia dengan manusia, manusia dengan alam lingkungan. Mata pelajaran Agama Hindu dan Budi Pekerti merupakan mata pelajaran yang melahirkan anak bangsa yang berkarakter dengan menanamkan nilai-nilai agama hindu dan budi pekerti. Pembentukan dan sikap yang mencerminkan budi pekerti menjadi salah satu aspek pencapaian afektif dari tujuan belajar Agama Hindu dan Budi Pekerti. Dalam hal ini, siswa yang memiliki sikap disiplin belajar dalam proses belajar Agama Hindu baik di rumah, sekolah, dan masyarakat maka siswa tersebut akan memiliki kesadaran dan melaksanakan budi pekerti yang berdasarkan pada Ajaran Agama Hindu yang telah siswa dapatkan dari buku, guru, orang tua, dan masyarakat.

Walaupun hasil penelitian ini, menunjukkan adanya korelasi positif yang signifikan antara disiplin belajar dengan budi pekerti siswa kelas V SD Saraswati 5 Denpasar, hasil penelitian ini memiliki validitas dan reliabilitas yang terbatas, karena dalam penelitian ini ada sejumlah variabel lain yang tentunya ikut berkorelasi dengan budi pekerti siswa tetapi tidak di perhitungkan. Hal ini tentu karena peneliti tidak melakukan penelitian variabel- variabel lainnya yang ikut berkorelasi dengan budi pekerti siswa. Disamping itu, studi korelasi antar dua variabel atau lebih bukanlah merupakan studi sebab akibat. Oleh karena itu, hasil penelitian ini atau temuan dalam penelitian ini haruslah dipergunakan secara hati-hati dan seksama sebagai dasar dalam membuat keputusan yang menyangkut Pendidikan Agama Hindu dan Budi Pekerti.

\section{SIMPULAN}

Berdasarkan pembahasan di atas, maka dapat disimpulkan: (1) Penelitian ini menemukan bahwa adanya korelasi yang positif dan signifikan antara disiplin belajar $\left(\mathrm{X}_{1}\right)$ dengan prestasi belajar $\left(\mathrm{Y}_{1}\right)$. Sehingga $\left(\mathrm{Ha}_{1}\right)$ disiplin belajar $\left(\mathrm{X}_{1}\right)$ berkorelasi positif yang signifikan dengan prestasi belajar siswa kelas $\mathrm{V}$ SD Saraswati 5 Denpasar $\left(\mathrm{Y}_{1}\right)$. (2) Penelitian ini menemukan bahwa antara disiplin belajar $\left(\mathrm{X}_{1}\right)$ dengan budi pekerti $\left(\mathrm{Y}_{2}\right)$ menunjukkan adanya korelasi yang positif dan signifikan. $\left(\mathrm{Ha}_{2}\right)$ disiplin belajar $\left(\mathrm{X}_{1}\right)$ berkorelasi positif yang signifikan dengan budi pekerti siswa kelas $\mathrm{V}$ SD Saraswati 5 Denpasar $\left(\mathrm{Y}_{2}\right)$. beberapa saran yang dapat diajukan bagi siswa, hendaknya melatih disiplin dalam belajar Agama Hindu dan Budi Pekerti untuk menggapai hasil belajar baik itu pada ranah kognitif yakni prestasi belajar dan ranah afektif yakni melaksanakan budi pekerti . Bagi Guru Agama Hindu dan Budi Pekerti, hendaknya memperhatikan sikap disiplin belajar dan budi pekerti siswa di kelas, karena setiap siswa memiliki disiplin belajar dan budi pekerti yang 
berbeda-beda. Sehingga, proses pembelajaran berjalan dengan baik dan tujuan serta hasil belajar kognitif (prestasi belajar) dan afektif (budi pekerti) dapat diraih dengan maksimal. Bagi sekolah, hendaknya mengadakan pengawasan yang lebih intens terhadap guru dan siswa, demi menerapkan pendidikan karakter yang digadang oleh sistem pendidikan sekarang ini. Salah satunya dengan penanaman dan penerapan karakter disiplin dan budi pekerti yang berdasarkan pada ajaran Agama oleh warga sekolah. Bagi peneliti lain, hasil penelitian ini dapat dijadikan acuan untuk penelitianpenelitian yang sejenis. Untuk kesempurnaan penelitian ini perlu diadakan penelitian lanjut yang melibatkan variabel-variabel lain, yang berkorelasi dengan prestasi belajar dan budi pekerti siswa.

\section{DAFTAR PUSTAKA}

Arikunto, Suharsimi. 2014. Prosedur Penelitian. Jakarta: PT. Rineka Cipta

Darmadi. 2017. Pengembangan Model dan Metode Pembelajaran dalam Dinamika Belajar Siswa. Jakarta: Deepublish.

Diatmika, Sujana, Putra (2017). Korelasi antara Disiplin dalam Belajar dengan Kompetensi Pengetahuan IPS Siswa Kelas IV SD Gugus 1 Kecamatan Mengwi Tahun Pelajaran 2016 - 2017, dalam Journal of Education Technology Vol. 1 No. (3) pp. 156-162. url https://ejournal.undiksha.ac.id/JET/article/download/12499/7829

Duwijo dan Darta, I Ketut. 2014. Buku Guru Pendidikan Agama Hindu dan Budi Pekerti Kelas V Sekolah Dasar. Jakarta: Kemendikbud.

Kristiyanti. 2016. Hubungan Disiplin Belajar Dengan Hasil Belajar Pkn Siswa Kelas IV Sd Se-Gugus Diponegoro Kecamatan Banyubiru, Kabupaten Semarang. (akses tanggal 28 November 2017), Tersedia dalam url http://lib.unnes.ac.id/

Sandika, Ketut. 2014. Membentuk Siswa Berkarakter Mulia melalui Pola Pembelajaran Pendidikan Agama Himdu Telaah Kitab Chandogya Upanisad. Surabaya: Paramitha.

Sudijono. 2012. Statistik Pendidikan. Jakarta: Rajawali Press.

Sudjana, Nana. 2013. Penilaian Hasil Proses Belajar Mengajar. Bandung: PT Remaja Rosdakarya.

$S$

Tulus, Tuu. 2004. Peran Disiplin pada Perilaku dan Prestasi Siswa. Jakarta: PT. Grasindo. 